\title{
Covid-19 \& Stigma of Patient Families and Health Workers in Makassar City, Indonesia
}

\author{
Covid-19 \& Stigma Pada Keluarga Pasien dan Petugas Kesehatan \\ di Kota Makassar, Indonesia
}

\author{
Abdul Gafur $^{* 1}$, Zainuddin ${ }^{2}$, Musdalifah $^{3}$, Safriadi Darmansyah ${ }^{4}$ \\ ${ }^{1,2}$ Bagian Kesehatan Masyarakat, Uniersitas Pejuang Republik Indonesia, Makassar \\ ${ }^{3,4}$ Bagian Keperawatan, Institut Kesehatan dan Bisnis St. Fatimah Mamuju, Mamuju
}

DOI: $10.24252 /$ al-sihah.v13i1.21463

Received: 16 June 2021 / In Reviewed: 18 June 2021 / Accepted: 26 June 2021 / Available online: 30 June 2021 (C) The Authors 2021. This is an open access article under the CC BY-NC-SA 4.0 license

\begin{abstract}
Covid-19 has now become an epidemic that has spread almost all over the world and has caused morbidity and mortality. covid-19 in addition to having an impact on physical health also has an impact on the social and economic life of the community as well as mental disorders due to the stigma experienced by infected people, families, and health workers. This study aims to determine the role of knowledge about community stigma towards health workers and families of covid-19 patients in Makassar City, Indonesia. In this study using a quantitative method with a descriptive survey approach, the sample in this study was 105 respondents, which were taken by simple random sampling technique. The study found that public knowledge about covid-19 was related to stigma in the families of covid-19 patients $(p=0.010)$ and knowledge was also associated with stigma to health workers $(p=0.000)$. Stigma against families and health workers still occurs in Makassar City, due to the lack of knowledge possessed by the community and the existence of fake news or hoaxes that trigger the emergence of stigma against health workers and families of covid-19 patients.
\end{abstract}

\begin{abstract}
ABSTRAK
Covid-19 saat ini telah menjadi wabah yang telah menyebar ke hampir seluruh dunia, dan telah menyebabkan angka kesakitan dan kematian. covid-19 selain menimbulkan dampak kesehatan secara fisik, juga menimbulkan dampak terhadap kehidupan sosial dan ekonomi masyarakat serta gangguan mental akibat stigma yang alami oleh orang yang terinfeksi, keluarga serta petugas kesehatan. Penelitian ini bertujuan untuk mengetahui peranan pengetahuan terhadap stigma masyarakat terhadap petugas kesehatan dan keluarga pasien covid-19 di Kota Makassar, Indonesia. Dalam penelitian ini digunakan metode kuantitatif dengan pendekatan survei deskriptif, sampel dalam penelitian ini adalah sebanyak 105 responden, yang diambil dengan teknik simple random sampling. Penelitian menemukan bahwa pengetahuan masyarakat tentang covid-19 berhubungan terhadap stigma pada keluarga pasien covid-19 $(\mathrm{p}=0,010)$ dan pengetahuan juga berhubungan dengan stigma pada petugas kesehatan $(p=0,000)$. Stigma kepada keluarga dan petugas kesehatan masih terjadi di Kota Makassar, sebab minimnya pengetahuan yang dimiliki oleh masyarakat serta adanya pemberitaan yang tidak benar atau hoaks menjadi pemicu munculnya stigma kepada petugas kesehatan dan keluarga pasien covid-19.
\end{abstract}

\section{GRAPHICAL ABSTRACT}

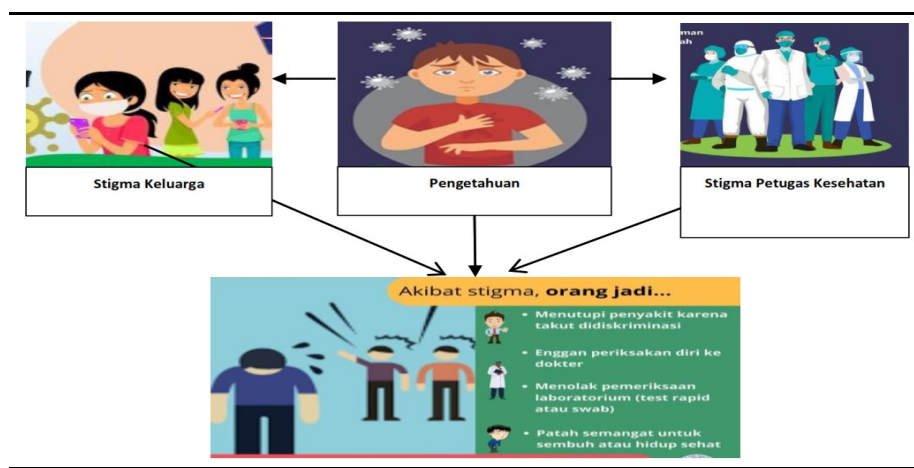

Keyword

covid-19; families of patients covid-19; health workers; knowledge; stigma

\section{Kata Kunci:}

covid-19; keluarga pasien covid-19; petugas kesehatan; pengetahuan; stigma

\section{* Correspondence}

Perumahan Baruga Samata Blok F.17. Gowa

Email: abdulgafurazis@gmail.com 


\section{PENDAHULUAN}

Penyakit coronavirus 2019 atau dikenal dengan covid-19 merupakan penyakit yang disebabkan karena Severe Acute Respiratory Syndrome Coronavirus-2 (SARS-COV-2), penyakit ini pertama kali dilaporkan terjadi di Wuhan, Cina pada akhir tahun 2019 (Lai et al., 2020). Covid19 saat ini telah menjadi wabah dan mengancam seluruh dunia dan menyebar dengan cepat yang menyebabkan kekhawatiran, kecemasan dan perubahan pada rutinitas keseharian masyarakat. Dampak lain yang paling banyak dirasakan oleh masyarakat dengan adanya pandemik ini ada terjadinya stigma oleh masyarakat, keluarga, dan teman (Lee et al., 2020; Liu et al., 2020; Taylor et al., 2020a).

Di Indonesia kasus covid-19 sampai dengan 31 Mei 2020 tercatat 26.473 kasus dengan kasus baru sebesar 700 kasus per hari, sehingga hal inilah yang membuat pemerintah Indonesia melakukan upaya pembatasan sosial berskala besar dan memilih untuk tidak melakukan lockdown seperti yang dilakukan oleh negara-negara lain, seperti Cina, Amerika dan banyak negara lainnya (Satuan Tugas Penanganan covid19, 2020; Ren, 2020; Samaraoudi et al., 2020).

Sulawesi Selatan merupakan salah satu provinsi yang cukup tinggi penularan kasus covid-19 dan Kota Makassar merupakan daerah episentrum penularan covid-19 di Sulawesi selatan. (Baso et al, 2021). Petugas kesehatan memiliki risiko yang cukup tinggi tertular covid-19, sebab mereka hampir setiap hari berinteraksi langsung dengan pasien covid-19, potensi lain yang muncul adalah petugas dapat menularkan kepada keluarga di rumah (Mhango et al., 2020), stigma ini terjadi karena adanya dorongan dari masyarakat untuk tetap bertahan dan tidak tertular covid-19 (Duan et al, 2020). Petugas kesehatan memiliki masalah ganda dalam penanganan pandemik covid-19, selain stigma dan diskriminasi juga mengalami masalah atau tekanan mental seperti stres, insomnia, depresi dan mengalami kecemasan (Fawas \& Samaha, 2020; Landa-Blanco et al., 2021; Pappa et al., 2020).

Stigma tidak hanya terjadi petugas kesehatan dan masyarakat yang terinfeksi covid-19, namun juga terjadi stigma terhadap keluarga pasien covid-19. (Li et al., 2021). Beberapa penelitian lain menunjukkan bahwa pandemi covid-19 membuat masyarakat menjadi menutup diri dari lingkungan bahkan menjadi paranoid, kecemasan masyarakat (Lopes et al., 2021; Roy et al., 2020; Kowalski et al., 2020). Beberapa penelitian mengenai stigma masyarakat yang lahir dari pengetahuan terhadap pasien covid telah dilakukan (Xue, 2021; Roy et al., 2020., Iqbal., 2021). Di Indonesia beberapa penelitian telah dilakukan namun hanya di daerah Indonesia Barat (Saefi et al., 2020; Rahman et al., 2020; Bela et al., 2021). Peneliti perlu mengetahui tingkat pengetahuan masyarakat terhadap lahirnya stigma di salah satu daerah episentrum di Indonesia Timur. Penelitian ini bertujuan untuk mengetahui peranan pengetahuan terhadap stigma masyarakat terhadap petugas kesehatan dan keluarga pasien covid-19 di Kota Makassar. 
Tabel 1

Pertanyan Mengenai Pengetahuan

\begin{tabular}{llc}
\hline Pertanyaan & Benar & Salah \\
\hline Covid-19 menyebabkan gangguan kesehatan khususnya pada jantung dan & 15,24 & 84,76 \\
Penularan covid-19 dapat dicegah melalui alat penutup mulut ? & 19,05 & 80,95 \\
Covid-19 dapat dicegah melalui cara cuci tangan dengan air & 23,81 & 76,19 \\
Sosial distancing adalah menjaga jarak dengan siapapun sehingga tidak & 25,71 & 74,29 \\
terluar covid-19 & 27,62 & 72,38 \\
Psycal distancing adalah Jaga jarak Fisik dan social & 20,00 & 80,00 \\
Pemakaman penderita Covid dapat menularkan kepada masyarakat sekitar & 20,00 & 80,00 \\
Istirahat yang kurang, seseorang dapat dengan mudah terkena covid-19 & 25,71 & 74,29 \\
Berjemur dapat mencegah dan membunuh virus covid-19 & 26,67 & 73,33 \\
Menggunakan Masker saat batuk dapat mencegah penularan covid-19 & 23,81 & 76,19 \\
Mencuci tangan dengan sabun tidak dapat mencegah penularan covid-19 & 29,52 & 70,48 \\
Makanan bergizi seimbang dapat menagkal covid-19 & 32,38 & 67,62 \\
Berkumpul dengan orang banyak tidak mempengaruhi penyebaran covid-19 & 36,19 & 63,81 \\
Pembatasan Sosial Berskala Besar salah satunya adalah dengan pembatasan &
\end{tabular}

\section{METODE PENELITIAN}

Penelitian ini menggunakan jenis penelitian kuantitatif dengan pendekatan pendekatan cross-sectional (potong lintang) bertujuan untuk memberikan gambaran tentang pengaruh pengetahuan terhadap stigma masyarakat terhadap petugas kesehatan dan keluarga pasien covid-19. Sampel dalam penelitian ini sebesar 105 responden, di mana sampel 100-400 merupakan sampel yang dianggap ideal untuk populasi yang cukup besar, sebab jika melebihi batas tersebut maka akan sangat sensitif dan sulit mendapatkan goodness of fit. Sampel diambil dengan menggunakan teknik simple random sampling. Penelitian ini dilakukan pada bulan April-Juli 2020. Instumen yang digunakan dalam penelitian ini adalah kuesioner dengan skala Likert, dimana telebih dahulu dilakukan uji coba terhadap kelayakan kuesioner yang dibuat, tkoesioner terdiri atas daftar pertanyaan mengenai pengetahuan mengenai covid-19 (tabel 1), serta daftar pertanyaan mengenai stigma pada keluarga pasien dan petugas kesehatan (tabel 2). Koesioner ini diperoleh dan dimodifikasi dari beberapa literature penelitian. Peneliti mengumpulkan data sekunder yang tersedia di Dinas Kesehatan Provinsi Sulawesi Selatan, Dinas Kesehatan Kota Makassar, serta dari tim gugus penanganan covid-19 Provinsi Sulawesi Selatan, dilanjutkan dengan penentuan sampel dan melakukan pengumpulan data primer, data dianalisis data dengan menggunakan aplikasi SPSS 17.0 for Windows (SPSS, Inc).

\section{HASIL PENELITIAN}

Penelitian ini dilakukan dengan menerapkan protokol kesehatan sebab dilakukan di masa pandemik covid-19, sebanyak 105 responden yang berhasil diwawancarai dalam penelitian ini yang tersebar di seluruh kecamatan yang ada di Kota Makassar. Hasil penelitian pada tabel 3 
Tabel 2

Pertanyan Mengenai Stigma

\begin{tabular}{|c|c|c|c|c|c|}
\hline Pertanyaan & $\begin{array}{l}\text { Sangat } \\
\text { Setuju }\end{array}$ & Setuju & $\begin{array}{l}\text { Ragu- } \\
\text { ragu }\end{array}$ & $\begin{array}{l}\text { Tidak } \\
\text { setuju }\end{array}$ & $\begin{array}{c}\text { Snagat } \\
\text { tidak } \\
\text { setuju }\end{array}$ \\
\hline \multicolumn{6}{|l|}{ Stigma keluarga pasien covid-19 } \\
\hline $\begin{array}{l}\text { Keluarga penderita covid-19 memiliki orang yang } \\
\text { harus dijauhi }\end{array}$ & 7 & 3 & 35 & 22 & 38 \\
\hline Keluarga penderita covid-19 sangat berbahaya & 0 & 3 & 12 & 43 & 47 \\
\hline Keluarga yang serumah penderita covid-19 sudah & 3 & 2 & 11 & 45 & 44 \\
\hline Keluarga pasien covid-19 juga dapat membawa & 4 & 4 & 35 & 18 & 44 \\
\hline \multicolumn{6}{|l|}{ Stigma Petugas Kesehatan } \\
\hline $\begin{array}{l}\text { Petugas Kesehatan adalah orang yang membawa } \\
\text { virus covid-19 di lingkungan sekitar }\end{array}$ & 12 & 17 & 23 & 30 & 23 \\
\hline $\begin{array}{l}\text { Petugas Kesehatan adalah orang yang sangat ber- } \\
\text { bahaya hidup disekitar kita }\end{array}$ & 17 & 23 & 7 & 32 & 26 \\
\hline $\begin{array}{l}\text { Petugas Kesehatan menyebabkan keresahan hidup } \\
\text { ditengah masyarakat umum }\end{array}$ & 12 & 18 & 12 & 35 & 28 \\
\hline $\begin{array}{l}\text { Petugas Kesehatan adalah orang yang harus } \\
\text { dihindari berinteraksi }\end{array}$ & 21 & 13 & 17 & 23 & 31 \\
\hline $\begin{array}{l}\text { Petugas penyebar virus dari satu pasien kepasien } \\
\text { lainnya }\end{array}$ & 18 & 26 & 10 & 24 & 27 \\
\hline
\end{tabular}

yang dilakukan terhadap 105 responden ditemukan bahwa sebanyak $71,4 \%$ adalah laki-laki dan perempuan $28.6 \%$. Umur responden yang diwawancarai terbanyak pada kelompok umur $>45$ tahun yaitu $45.9 \%$, umur 26-45 tahun sebesar $42,9 \%$, umur $<25$ tahun paling kecil yaitu 7,6\%, Berdasarkan tingkat pendidikan lebih banyak pada sekolah menengah atas yaitu 50.5\%, perguruan tinggi sebesar 30,5\%, sekolah menengah pertama sebesar $15,25 \%$ Sekolah Dasar, 2,9\% serta yang tidak sekolah hanya $1 \%$, Berdasarkan pekerjaan responden lebih dominan pada yang tidak bekerja yaitu $33.3 \%$, kemudian wiraswasta sebesar $41 \%$, karyawan swasta $16,2 \%$, pegawai negeri sipil 5,7\% serta buruh dan petani masingmasing $1,9 \%$.

Hasil penelitian pada tabel 4 menunjukkan hubungan pengetahuan dengan stigma terhadap keluarga pasien covid-19, di mana dari 28 responden yang memiliki pengetahuan kurang terdapat 6 responden $(21,4 \%)$ yang melakukan stigma pada petugas kesehatan dan sebanyak 22 responden (78,6\%) yang tidak melakukan stigma terhadap keluarga pasien. Selain itu dari 77 responden dengan pengetahuan cukup, terdapat 3 responden $(3,9 \%)$ yang melakukan stigma terhadap keluarga pasien covid-19 dan sebanyak 74 responden $(96,1 \%)$ yang tidak melakukan stigma terhadap keluarga pasien covid-19. Hasil uji statistik juga menunjukkan bahwa ada hubungan tingkat pengetahuan masyarakat dengan stigma terhadap keluarga pasien covid-19 dengan nilai $\mathrm{p}=0,010$.

Tabel 5 menunjukkan bahwa dari 28 responden yang memiliki pengetahuan kurang terdapat 16 responden $(57,1 \%)$ yang melakukan stigma kepada petugas kesehatan dan sebesar 12 responden 
Tabel 3

Karakteristik Responden

\begin{tabular}{|c|c|c|}
\hline Karakteristik & Jumlah & Persen \\
\hline \multicolumn{3}{|l|}{ Jenis kelamin } \\
\hline Laki-laki & 75 & 71.4 \\
\hline Perempuan & 30 & 28.6 \\
\hline \multicolumn{3}{|l|}{ Umur } \\
\hline$<25$ tahun & 8 & 7.6 \\
\hline 26-45 tahun & 45 & 42.9 \\
\hline$>45$ tahun & 52 & 49.5 \\
\hline \multicolumn{3}{|l|}{ Pendidikan } \\
\hline Tidak pernah sekolah & 1 & 1 \\
\hline Sekolah dasar & 3 & 2.9 \\
\hline Sekolah menengah pertama & 16 & 15.2 \\
\hline Sekolah menengah atas & 53 & 50.5 \\
\hline Perguruan tinggi & 32 & 30.5 \\
\hline \multicolumn{3}{|l|}{ Pekerjaan } \\
\hline PNS & 6 & 5.7 \\
\hline Karyawan swasta & 17 & 16.2 \\
\hline Wiraswasta & 43 & 41 \\
\hline Buruh & 2 & 1.9 \\
\hline Petani & 2 & 1.9 \\
\hline Tidak bekerja & 35 & 33.3 \\
\hline
\end{tabular}

(42,9\%) yang tidak melakukan stigma terhadap petugas kesehatan. Selain itu dari 77 responden yang memiliki pengetahuan cukup, terdapat 13 responden (16,9\%) yang melakukan stigma terhadap petugas kesehatan dan sebesar 64 responden $(83,1 \%)$. Hasil uji statistik juga menunjukkan bahwa ada hubungan tingkat pengetahuan masyarakat dengan stigma terhadap petugas kesehatan dengan nilai $\mathrm{p}=0,000$.

\section{PEMBAHASAN}

Covid-19 saat ini telah menjadi pandemik yang menyebar ke seluruh penjuru dunia, dan telah mengalami peningkatan kasus yang cukup tinggi (Komarova et al., 2020; Kenyon, 2020). Rendahnya angka testing, tingginya mobilitas, dan upaya distribusi vaksinasi masih terhambat sehingga menimbulkan lonjakan kasus covid-19 di seluruh dunia (Omori et al., 2020; Zhou et al., 2020).

Semakin berkembangnya media sosial yang ada saat ini, sangat berdampak pada pengetahuan, sikap dan tindakan masyarakat, khususnya terkait dengan wabah covid-19, masyarakat terpolarisasi dalam menggapi isu covid-19, ada yang menanggapi masalah ini hanyalah masalah biasa-biasa saja dan tidak perlu dibesarbesarkan, di sisi lain banyak menganggap covid-19 ini sebagai wabah yang mematikan dan mengancam kehidupan umat manusia sehingga harus dihindari (Gbashi, 2021). Muncul pula persepsi yang cukup ekstrem dari beberapa kelompok masyarakat yaitu melakukan stigma terhadap petugas kesehatan yang menangani covid-19, 
Tabel 4

Hubungan Pengetahuan Terhadap Stigma Keluarga Pasien covid-19

\begin{tabular}{|c|c|c|c|c|c|c|}
\hline \multirow[t]{3}{*}{ Pengetahuan } & \multicolumn{4}{|c|}{ Stigma Keluaga Pasien } & \multirow[t]{3}{*}{ Total } & \multirow[t]{3}{*}{$p$} \\
\hline & \multicolumn{2}{|c|}{$\mathrm{Ya}$} & \multicolumn{2}{|c|}{ Tidak } & & \\
\hline & $\mathrm{n}$ & $\%$ & $\mathrm{n}$ & $\%$ & & \\
\hline Kurang & 6 & 21.4 & 22 & 78,6 & 28 & \\
\hline Cukup & 3 & 3.9 & 74 & 96.1 & 77 & 0,010 \\
\hline Jumlah & 9 & 8,6 & 96 & 91,4 & 105 & \\
\hline
\end{tabular}

bahkan ada pula yang tidak bersedia atau keberatan jika ada petugas kesehatan yang menangani covid-19 pulang di rumah, karena ditakutkan akan menularkan kepada keluarga dan masyarakat sekitar. (Wahed et al., 2020; Singh \& Subedi, 2020).

Stigma yang dialami oleh petugas kesehatan menjadi beban ganda bagi petugas kesehatan, di mana mereka harus beradaptasi dengan kondisi dilema yang saat ini sedang dihadapi (Tang, 2020). Kondisi yang dialami di antaranya kejenuhan, perasaan khawatir, ketakutan akan menularkan kepada keluarga, ditambah dengan semakin tidak jelasnya kapan keadaan ini kembali normal lagi, kondisi ini akan menjadi persoalan yang terus dihadapi oleh masyarakat yang perlu mendapat perhatian dari seluruh elemen agar masyarakat tetap sehat dan sejahtera (Ardebili et al., 2021; Rosyanti, 2020).

Adanya kebijakan dan informasi untuk menjaga jarak dengan orang lain (social distancing) kemudian banyak menimbulkan polemik. Banyaknya informasi salah atau hoaks dan minimnya informasi yang diterima oleh masyarakat, sehingga banyak masyarakat yang melakukan perlakukan diskriminatif, baik warga yang ingin pulang dari kota ke desa, perawat atau dokter yang dari bertugas di puskesmas/rumah sakit, bahkan sampai penolakan jenasah (Sahu, 2020; Sulistiadi et al., 2020; Purwanti \& Pramana, 2020).

Kondisi ini menjadi sangat krusial, sebab dukungan sosial yang diharapkan penderita dari keluarga, sahabat dan masyarakat, justru menjadi masalah baru yang dihadapi oleh petugas kesehatan dan keluarga dari orang yang meninggal karena covid-19. Minimnya dukungan sosial kepada pengidap covid-19 serta keluarga menimbulkan masalah baru pada penderita dan keluarga, dimana mereka akan merasakan kesepian, ketidakpercayaan terhadap masyarakat, perasaan kehilangan teman (Dubey et al., 2020; Ghosh et al., 2020). Hilangnya dukungan sosial terhadap pen-

Tabel 5

Hubungan Pengetahuan Terhadap Stigma Petugas Kesehatan

\begin{tabular}{|c|c|c|c|c|c|c|}
\hline \multirow[t]{3}{*}{ Pengetahuan } & \multicolumn{4}{|c|}{ Stigma terhadap petugas kesehatan } & \multirow[t]{3}{*}{ Total } & \multirow[t]{3}{*}{$p$} \\
\hline & \multicolumn{2}{|c|}{$\mathrm{Ya}$} & \multicolumn{2}{|c|}{ Tidak } & & \\
\hline & $\mathrm{n}$ & $\%$ & $\mathrm{n}$ & $\%$ & & \\
\hline Kurang & 16 & 7,7 & 12 & 92,3 & 28 & \\
\hline Cukup & 13 & 21,3 & 64 & 55,7 & 77 & 0,000 \\
\hline Jumlah & 29 & 27,6 & 76 & 72,4 & 105 & \\
\hline
\end{tabular}


derita dan keluarga memunculkan perasaan kesepian (loneliness), kondisi di mana individu merasa tidak puas dengan relasi interpersonal berupa hilang atau berkurangnya kehadiran teman atau orang lain dalam kehidupannya (Berg-Weger \& Morley, 2020).

Hasil penelitian ini menemukan bahwa terdapat pengaruh bahwa tingkat pengetahuan akan mempengaruhi cara seseorang memandang orang yang terinfeksi covid-19. Hal ini sejalan dengan penelitian yang dilakukan oleh Islam et al., (2021) yang melakukan uji lapangan secara acak di negara bagian Uttar Pradesh, India. Hasil penelitian bahwa informasi singkat mengurangi stigma terhadap pasien covid19 dan kelompok-kelompok tertentu seperti agama minoritas, kelompok kasta bawah, dan pekerja garis depan (kesehatan, polisi), dan mengurangi keyakinan bahwa kasus infeksi lebih banyak terjadi di kalangan sosial dan ekonomi tertentu yang terpinggirkan seperti muslim, kasta rendah, penduduk pedesaan yang miskin.

Pengetahuan masyarakat menjadi pemicu terjadinya stigma di masyarakat, masyarakat saat ini lebih banyak mendapatkan informasi dari media sosial, tanpa melakukan proses penyaringan atau verifikasi kebenaran informasi yang didapatkan, sehingga yang dibutuhkan saat ini oleh masyarakat adalah edukasi secara masif agar perilaku sosial yang positif mereka terbentuk dan menjadi lebih baik (Li et al., 2020). Perlakukan diskriminatif dan stigma negatif pada penderita, keluarga dan tenaga medis, akan menyebabkan penderita semakin frustrasi, kecewa dan menyebabkan mereka kehilangan arah dan berdampak buruk terhadap kesehatan fisik dan psikis (Stangl et al., 2019; Handayani et al., 2020).

Temuan penelitian ini menunjukkan bahwa semakin rendah pengetahuan dan literasi kesehatan seseorang maka semakin tinggi potensi stigma terhadap tenaga kesehatan akan terjadi. Hal ini sejalan dengan penelitian yang dilakukan oleh $\mathrm{Ra}$ maci et al. (2020) yang meneliti 460 tenaga kesehatan di Italia Selatan yang memperoleh sikap diskriminasi, penerimaan, dan ketakutan yang terpapar covid-19. Temuan menunjukkan bahwa stigma memiliki dampak yang tinggi pada hasil pekerja. Stigma dapat memengaruhi kepatuhan pekerja dan dapat memandu strategi komunikasi manajemen terkait risiko pandemi bagi petugas kesehatan. Selain itu penelitian yang dilakukan oleh Taylor et al. (2020a) yang meneliti non-petugas kesehatan dari Amerika Serikat dan Kanada sebanyak 3551 orang melalui survei online menemukan bahwa lebih dari seperempat responden percaya bahwa petugas kesehatan harus memiliki pembatasan ketat terhadap kebebasan mereka, seperti diasingkan dari komunitas dan keluarga mereka. Selain itu, lebih dari sepertiga responden menghindari petugas kesehatan karena takut terinfeksi. Orang-orang yang memberikan stigma kepada petugas kesehatan juga cenderung menghindari orang lain, menghindari toko obat, dan supermarket, serta menetap di rumah mereka.

Petugas kesehatan merupakan salah satu garda terdepan dalam menangani pasien covid-19 yang semakin hari terus mengalami peningkatan kasus dan membu- 
at petugas kesehatan mengalami kelelahan kerja berlebih (Yıldırım \& Solmaz, 2020). Selain itu masyarakat banyak yang menganggap bahwa petugas kesehatan adalah salah satu pembawa dan penyebar virus yang sangat potensial. Sehingga terjadi stigma terhadap petugas kesehatan, kondisi ini memicu terjadinya gangguan kesehatan mental seperti stres, insomnia, depresi, dan kecemasan dari petugas kesehatan (Fawas \& Samaha, 2020). Untuk itulah, kiranya dibutuhkan upaya untuk menggerakkan kembali dukungan sosial pada saat-saat seperti sekarang ini (Horesh \& Brown, 2020). Selain itu, upaya yang dilakukan agar mengurangi dampak yang lebih besar dari petugas kesehatan yang mengalami stigma, maka petugas kesehatan perlu diberikan intervensi berupa relaksasi, olahraga, meditasi, akupuntur (Canady, 2020).

Pada kondisi saat ini, tenaga kesehatan memiliki beban kerja yang sangat besar yang disebabkan karena kondisi covid -19 yang semakin mengalami peningkatan kasus setiap hari. Adanya peningkatan kasus disebabkan banyaknya jumlah pasien yang tidak tertangani di layalanan kesehatan yang disebabkan oleh keterbatasan jumlah tenaga kesehatan dan alat pelinding diri, sehingga banyak masyarakat yang tidak bisa mendapatkan pengobatan covid-19 dan menimbulkan angka kematian yang semakin meningkat.(Abaluck et al. 2020; Tsermoulas et al., 2020). Munculnya inforamasi salah atau tidak benar yang didapatkan oleh masyarakat sehingga banyak juga masyarakat yang tidak memanfaatkan layanan kesehatan dan memunculkan stigma dan diskriminasi, oleh sebab itu maka perlu dilakukan edukasi oleh petugas untuk meluruskan informasi yang salah tersebut agar persoalan tersebut dapat diatasi, selain itu pemerintah juga telah melakukan berbagai upaya untuk meminimalisir penyebaran informasi yang kurang benar melalui media sosial (Lovari, 2020). Dampak negatif lain yang ditimbulkan dari adanya stigma adalah ketidakterbukaan orang yang memiliki gejala kepada keluarga, masyarakat dan petugas kesehatan (Chew et al., 2021; Shok, \& Beliakova, 2020). Hal tersebut timbul karena ketakutan akan di isolasi mandiri yang berakibat mengganggu stabilitas ekonomi keluarga, selain itu masyarakat tidak dapat memanfaatkan layanan kesehatan karena takut didiagnosis covid-19.

\section{KESIMPULAN}

Stigma kepada keluarga dan petugas kesehatan masih terjadi di Kota Makassar, sebab minimnya pengetahuan yang dimiliki oleh masyarakat serta adanya pemberitaan yang tidak benar atau hoaks menjadi pemicu munculnya stigma kepada petugas kesehatan dan keluarga pasien covid-19. Disarankan penerapan aturan dan kebijakan perundang-undangan sangat penting dalam mencegah dan mengendalikan penularan covid-19, serta dibutuhkan kerja sama semua pihak untuk memberikan edukasi kepada masyarakat, agar mau bersama-sama memberikan dukungan moral dan dukungan sosial kepada keluarga pasien covid-19 dan petugas kesehatan, sehingga dampak stigma seperti trauma mental dapat diminimalisir dan dihilangkan. 


\section{DAFTAR PUSTAKA}

Abaluck, J., Chevalier, J. A., Christakis, N. A., Forman, H. P., Kaplan, E. H., Ko, A., \& Vermund, S. H. (2020). The case for universal cloth mask adoption and policies to increase supply of medical masks for health workers. SSRN 3567438. https:// dx.doi.org/10.2139/ssrn.3567438

Anwar, A., Malik, M., Raees, V., \& Anwar, A. (2020). Role of mass media and public health communications in the covid-19 pandemic. Cureus, 12(9). https:// dx.doi.org/10.7759\%2Fcureus. 10453

Ardebili, M. E., Naserbakht, M., Bernstein, C., Alazmani-Noodeh, F., Hakimi, H., \& Ranjbar, H. (2021). Healthcare providers experience of working during the covid-19 pandemic: A qualitative study. American journal of infection control, 49(5), 547-554. https://doi.org/10.1016/j.ajic.2020.10.001

Baso, F., Darmawansyah, A. R., Arifin, M. A., Saleh, L. M., \& Syafar, M. (2021). Analysis of Factors Affecting the Implementation of the covid-19 Management Program in the City of Makassar. Annals of the Romanian Society for Cell Biology, 25(6), 6962-6974. https://www.annalsofrscb.ro/index.php/ journal/article/view/6812

Bela, G. S., Pusporini, L. S., Marwiyah, N., \& Kuntarto, B. (2021). Gambaran Pengetahuan, Sikap, dan Tingkat Kecemasan Masyarakat tentang Kejadian covid-19 di Lingkungan Perumahan Taman Banten Lestari Kota Serang Tahun 2020. Faletehan Health Journal, 8(01), 42-50. https:// doi.org/10.33746/fhj.v8i01.198

Berg-Weger, M., \& Morley, J. E. (2020). Loneliness and social isolation in older adults during the covid-19 pandemic: Implications for gerontological social work. The journal of nutrition, health \& aging, 24, 456-458 . https://doi.org/10.1007/s12603-020-1366-8

Canady, V. A. (2020). COVID $\square 19$ outbreak represents a new way of mental health service delivery. Mental Health Weekly, 30(12), 14. https://doi.org/10.1002/mhw.32282

Chew, C. C., Lim, X. J., Chang, C. T., Rajan, P., Nasir, N., \& Low, W. Y. (2021). Experiences of Social Stigma Among Patients Tested Positive for covid-19 and Their Family Members: A Qualitative Study. BMC Public Health. https://doi.org/10.21203/rs.3.rs-153721/v1

Chong, Y. Y., Cheng, H. Y., Chan, H. Y. L., Chien, W. T., \& Wong, S. Y. S. (2020). covid-19 pandemic, infodemic and the role of eHealth literacy. International journal of nursing studies, 108, 103644. https://dx.doi.org/10.1016\%2Fj.ijnurstu. 20 20.103644

Duan, W., Bu, H., \& Chen, Z. (2020). covid-19related stigma profiles and risk factors among people who are at high risk of contagion. Social Science \& Medicine, 266, 113425 .

https://doi.org/10.1016/j.socscimed.2020.11 3425

Dubey, S., Biswas, P., Ghosh, R., Chatterjee, S., Dubey, M. J., Chatterjee, S., \& Lavie, C. J. (2020). Psychosocial impact of covid19. Diabetes \& Metabolic Syndrome: Clinical Research \& Reviews, 14(5), 779-788. https://doi.org/10.1016/j.dsx.2020.05.035

Fawaz, M., \& Samaha, A. (2020). The psychosocial effects of being quarantined following exposure to covid-19: A qualitative study of Lebanese health care workers. International Journal of Social Psychiatry, 66(6), 560565. https://doi.org/10.1177\%2F0020764020932 202

Gbashi, S., Adebo, O. A., Doorsamy, W., \& Njobeh, P. B. (2021). Systematic Delineation of Media Polarity on covid-19 Vaccines in Africa: Computational Linguistic Modeling Study. JMIR medical informatics, $9(3)$, e22916. https://doi.org/10.2196/22916

Ghosh, R., Dubey, M. J., Chatterjee, S., \& Dubey, S. (2020). Impact of covid-19 on children: special focus on the psychosocial aspect. Minerva Pediatrica, 72(3), 226-235. https://doi.org/10.23736/s00264946.20.05887-9

Handayani, R. T., Kuntari, S., Darmayanti, A. T., Widiyanto, A., \& Atmojo, J. T. (2020). Factors Causing Stress in Health and Community When the covid-19 Pandemic. Jurnal Keperawatan Jiwa, 8(3), 353. https://doi.org/10.26714/jkj.8.3.2020.353360

Horesh, D., \& Brown, A. D. (2020). covid-19 response: Traumatic stress in the age of covid-19: A call to close critical gaps and 
adapt to new realities. Psychological Trauma: Theory, Research, Practice, and Policy, 12(4), 331-335. https://doi.org/10.1037/TRA0000592

Iqbal, M. A., \& Younas, M. Z. (2021). Public knowledge, attitudes, and practices towards covid-19 in Pakistan: A cross-sectional study. Children and Youth Services Review, 120, 105784. https://doi.org/10.1016/j.childyouth.2020.10 5784

Islam, A., Pakrashi, D., Vlassopoulos, M., \& Wang, L. C. (2021). Stigma and misconceptions in the time of the covid-19 pandemic: A field experiment in India. Social Science \& Medicine, 278 , 113966. https://doi.org/10.1016/j.socscimed.2021.11 3966

Islam, M. S., Sarkar, T., Khan, S. H., Kamal, A. H. M., Hasan, S. M., Kabir, A., \& Seale, H. (2020). covid-19-related infodemic and its impact on public health: A global social media analysis. The American Journal of Tropical Medicine and Hygiene, 103(4), 1621.

https://dx.doi.org/10.4269\%2Fajtmh.200812

Kenyon, C. (2020). Flattening-the-curve associated with reduced covid-19 case fatality rates-an ecological analysis of 65 countries. Journal of Infection, 81(1), e98-e99. https://doi.org/10.1016/j.jinf.2020.04.007

Komarova, N. L., Schang, L. M., \& Wodarz, D. (2020). Patterns of the covid-19 pandemic spread around the world: exponential versus power laws. Journal of the Royal Society Interface, 17(170), 20200518. https://doi.org/10.1098/rsif.2020.0518

Kowalski, J., Marchlewska, M., Molenda, Z., Górska, P., \& Gawęda, Ł. (2020). Adherence to safety and self-isolation guidelines, conspiracy and paranoia-like beliefs during covid-19 pandemic in Poland-associations and moderators. Psychiatry Research, 294, 113540

https://doi.org/10.1016/j.psychres.2020.113 540

Lai, C. C., Wang, C. Y., Wang, Y. H., Hsueh, S. C., Ko, W. C., \& Hsueh, P. R. (2020). Global epidemiology of coronavirus disease 2019 (COVID-19): disease incidence, daily cumulative index, mortality, and their association with country healthcare resources and economic status. International journal of antimicrobial agents, 55(4). https://doi.org/10.1016/j.ijantimicag.2020.10 5946

Landa-Blanco, M., Mejía, C. J., Landa-Blanco, A. L., Martínez-Martínez, C. A., Vásquez, D., Vásquez, G., \& Montoya, B. D. (2021). Coronavirus awareness, confinement stress, and mental health: Evidence from Honduras, Chile, Costa Rica, Mexico and Spain. Social Science \& Medicine, 277, 113933. https://doi.org/10.1016/j.socscimed.2021.113 933

Lee, S. A., Mathis, A. A., Jobe, M. C., \& Pappalardo, E. A. (2020). Clinically significant fear and anxiety of covid-19: A psychometric examination of the Coronavirus Anxiety Scale. Psychiatry research, 290, 113112. https://doi.org/10.1016/j.psychres.2020.1131 12

Li, T., Bu, H., \& Duan, W. (2021). A brief measure of perceived courtesy and affiliate stigma on covid-19: A study with a sample from China. Personality and Individual Differences, 180, 110993. https://doi.org/10.1016/j.paid.2021.110993

Li, Y., Twersky, S., Ignace, K., Zhao, M., Purandare, R., Bennett-Jones, B., \& Weaver, S. R. (2020). Constructing and Communicating covid-19 Stigma on Twitter: A Content Analysis of Tweets during the Early Stage of the covid-19 Outbreak. International Journal of Environmental Research and Public Health, 17(18), 6847.

https://doi.org/10.3390/ijerph17186847

Liu, K., Chen, Y., Wu, D., Lin, R., Wang, Z., \& Pan, L. (2020). Effects of progressive muscle relaxation on anxiety and sleep quality in patients with covid-19. Complementary Therapies in Clinical Practice, 39, 101132. https://doi.org/10.1016/j.ctcp.2020.101132

Lopes, B., Bortolon, C., \& Jaspal, R. (2020). Paranoia, hallucinations and compulsive buying during the early phase of the covid-19 outbreak in the United Kingdom: a preliminary experimental study. Psychiatry Research, 293, 113455. https://doi.org/10.1016/j.psychres.2020.113 455

Lovari, A. (2020). Spreading (dis) trust: covid-19 
misinformation and government intervention in Italy. Media and Communication, 8(2), 458-461. https://doi.org/10.17645/mac.v8i2.3219

Mhango, M., Dzobo, M., Chitungo, I., \& Dzinamarira, T. (2020). covid-19 risk factors among health workers: a rapid review. Safety and Health at Work, 11(3), 2020. https://doi.org/10.1016/j.shaw.2020.06.001

Omori, R., Mizumoto, K., \& Chowell, G. (2020). Changes in testing rates could mask the novel coronavirus disease (COVID-19) growth rate. International Journal of Infectious Diseases, 94, 116-118. https://doi.org/10.1016/j.ijid.2020.04.021

Pappa, S., Ntella, V., Giannakas, T., Giannakoulis, V. G., Papoutsi, E., \& Katsaounou, P. (2020). Prevalence of depression, anxiety, and insomnia among healthcare workers during the covid-19 pandemic: A systematic review and meta-analysis. Brain, behavior, and immunity. 88, 901-907. https://doi.org/10.1016/j.bbi.2020.05.026

Purwanti, S. H., \& Pramana, C. (2020). Management Of Corpses With covid-19: Perspective On Cases In Indonesia. Journal of Health and Translational Medicine, 6-9. https://jummec.um.edu.my/article/view/236 65

Rahman, N. E., Tyas, A. W., \& Nadhilah, A. (2020). Hubungan pengetahuan tentang covid-19 terhadap sikap stigma masyarakat pada orang yang bersinggungan dengan covid-19. Share: Social Work Journal, 10(2), 209-215. https://doi.org/10.24198/share.v10i2.29614

Ramaci, T., Barattucci, M., Ledda, C., \& Rapisarda, V. (2020). Social stigma during covid19 and its impact on HCWs outcomes. Sustainability, 12(9), 3834. https://doi.org/10.3390/su12093834

Ren, X. (2020). Pandemic and lockdown: a territorial approach to covid-19 in China, Italy and the United States. Eurasian Geography and Economics, 61(4-5), 423-434. https://doi.org/10.1080/15387216.2020.176 2103

Rosyanti, L., \& Hadi, I. (2020). Dampak Psikologis dalam Memberikan Perawatan dan Layanan Kesehatan Pasien covid-19 pada Tenaga Profesional Kesehatan. Health Information :
Jurnal Penelitian, 12(1), 107-130. https://doi.org/10.36990/hijp.vi.191

Roy, D., Tripathy, S., Kar, S. K., Sharma, N., Verma, S. K., \& Kaushal, V. (2020). Study of knowledge, attitude, anxiety \& perceived mental healthcare need in Indian population during covid-19 pandemic. Asian journal of psychiatry, 51, 102083. https://doi.org/10.1016/j.ajp.2020.102083

Saefi, M., Fauzi, A., Kristiana, E., Adi, W. C., Muchson, M., Setiawan, M. E., \& Ramadhani, M. (2020). Survey data of covid-19related knowledge, attitude, and practices among indonesian undergraduate students. Data in $\quad$ brief, 31, 105855. https://doi.org/10.1016/j.dib.2020.105855

Sahu, S. A. (2020). Discrimination Against Healthcare Professionals By Society Amidst covid-19 Pandemic. European Journal of Molecular \& Clinical Medicine, 7(11), 3135-3143. https://ejmcm.com/article_6341.html

Samaroudi, M., Echavarria, K. R., \& Perry, L. (2020). Heritage in lockdown: digital provision of memory institutions in the UK and US of America during the covid-19 pandemic. Museum Management and Curatorship, 35(4), 337-361. https://doi.org/10.1080/09647775.2020.181 0483

Satuan Tugas Penanganan covid-19. (2020, May 5). Peta Sebaran covid-19. https://covid19.go.id/peta-sebaran

Shok, N., \& Beliakova, N. (2020). How Soviet Legacies Shape Russia's Response to the Pandemic: Ethical Consequences of a Culture of Non-Disclosure. Kennedy Institute of Ethics Journal,30(3), 379-400. https://doi.org/10.1353/ken.2020.0020

Singh, R., \& Subedi, M. (2020). covid-19 and stigma: Social discrimination towards frontline healthcare providers and covid-19 recovered patients in Nepal. Asian journal of psychiatry.

https://dx.doi.org/10.1016\%2Fj.ajp.2020.10 2222

Stangl, A. L., Earnshaw, V. A., Logie, C. H., van Brakel, W., Simbayi, L. C., Barré, I., \& Dovidio, J. F. (2019). The health stigma and discrimination framework: a global, crosscutting framework to inform research, intervention development, and policy on 
health-related stigmas. BMC medicine, 17(1),

$1-13$.

https://doi.org/10.1186/s12916-019-1271-3

Sulistiadi, W., Slamet, S. R., \& Harmani, N. (2020). Handling of Public Stigma on covid-19 in Indonesian Society. Kesmas: Jurnal Kesehatan Masyarakat Nasional (National Public Health Journal). http://dx.doi.org/10.21109/kesmas.v15i2.39 09

Tang, L. H., Tang, S., Chen, X. L., Zhang, S., Xiong, Y., Chen, R., ... \& Meng, Q. T. (2020). Avoiding health worker infection and containing the coronavirus disease 2019 pandemic: perspectives from the frontline in Wuhan. International Journal of Surgery. https://doi.org/10.1016/j.ijsu.2020.05.060

Taylor, S., Landry, C. A., Paluszek, M. M., Rachor, G. S., \& Asmundson, G. J. (2020b). Worry, avoidance, and coping during the covid-19 pandemic: A comprehensive network analysis. Journal of anxiety disorders, 76, 102327. https://doi.org/10.1016/j.janxdis.2020.10232 7

Taylor, S., Landry, C. A., Rachor, G. S., Paluszek, M. M., \& Asmundson, G. J. (2020a). Fear and avoidance of healthcare workers: An important, under-recognized form of stigmatization during the covid-19 pandemic. Journal of Anxiety Disorders, 75, 102289. https://doi.org/10.1016/j.janxdis.2020.10228

Tsermoulas, G., Zisakis, A., Flint, G., \& Belli, A. (2020). Challenges to Neurosurgery During the Coronavirus Disease 2019 (COVID-19) Pandemic. World Neurosurgery, 139, 519
525.

https://doi.org/10.1016/j.wneu.2020.05.108

Wahed, W. Y. A., Hefzy, E. M., Ahmed, M. I., \& Hamed, N. S. (2020). Assessment of knowledge, attitudes, and perception of health care workers regarding covid-19, a cross-sectional study from Egypt. Journal of community health, 45(6), 1242-1251. https://doi.org/10.1007/s10900-020-00882-0

Xiang, Y. T., Yang, Y., Li, W., Zhang, L., Zhang, Q., Cheung, T., \& Ng, C. H. (2020). Timely mental health care for the 2019 novel coronavirus outbreak is urgently needed. The Lancet Psychiatry, 7(3), 228-229. https://doi.org/10.1016/S22150366(20)30046-8

Xue, Q., Xie, X., Liu, Q., Zhou, Y., Zhu, K., Wu, H., Wang, Z., Feng, Y., \& Song, R. (2021). Knowledge, attitudes, and practices towards covid-19 among primary school students in Hubei Province, China. Children and youth services review, 120, 105735. https://doi.org/10.1016/j.childyouth.2020.10 5735

Yıldırım, M., \& Solmaz, F. (2020). covid-19 burnout, covid-19 stress and resilience: Initial psychometric properties of covid-19 Burnout Scale. Death Studies, 0(0), 1-9. https://doi.org/10.1080/07481187.2020.1818 885

Zhou, Y., Xu, R., Hu, D., Yue, Y., Li, Q., \& Xia, J. (2020). Effects of human mobility restrictions on the spread of covid-19 in Shenzhen, China: a modelling study using mobile phone data. The Lancet Digital Health, 2(8), e417-e424. https://doi.org/10.1016/S25897500(20)30165-5 